Journal of Animal and Veterinary Advances 11 (8): 1116-1122, 2012

ISSN: $1680-5593$

(C) Medwell Journals, 2012

\title{
Effects of Biotin and Rumen-Protected Choline Supplementation on Milk Production, Milk Composition, Live Weight Change and Blood Parameters in Lactating Dairy Cows
}

\author{
W. Suksombat, J. Homkao and P. Klangnork \\ School of Animal Production Technology, Institute of Agricultural Technology, \\ Suranaree University of Technology, University Avenue, Amphur Muang, \\ 30000 Nakhon Ratchasima, Thailand
}

\begin{abstract}
The objective of this study was to determine the effects of biotin and rumen-protected choline supplementation on milk production, milk composition, live weight change, milk choline and blood parameters in crossbred Holstein Friesian dairy cows. Twenty four Holstein Friesian crossbred lactating dairy cows, averaging $48 \pm 13$ days in milk, $15.5 \pm 0.8 \mathrm{~kg}$ of milk and $380 \pm 19 \mathrm{~kg}$ body weight were blocked by milking days first and then stratified random balanced for milk yield and body weight into 3 groups of 8 cows. The 1st group (control) received approximately $6 \mathrm{~kg}$ of $21 \% \mathrm{CP}$ concentrate. The 2 nd group was fed the same basal diet as the control group and supplemented with $20 \mathrm{mg}^{-1 a y}{ }^{-1}$ of Biotin (BASF (Thai) Co., Ltd.) filled in a capsule and $20 \mathrm{~g} \mathrm{RPC}$ day $^{-1}$ top-dressed (Reashure ${ }^{\circledR}$, Balchem Co., Ltd.) and the 3rd group was fed the same basal diet as the control group and supplemented with $20 \mathrm{mg}^{-1 a y}{ }^{-1}$ of biotin filled in a capsule and $40 \mathrm{~g} \mathrm{RPC} \mathrm{day}^{-1}$ topdressed. All cows also received ad libitum grass silage (Brachiaria ruziziensis; 55 days cutting age) had free access to clean water and were individually housed in a free-stall unit and individually fed according to treatments. The experiment lasted for 10 weeks with the 1 st 2 weeks as the adjustment period followed by 8 weeks of measurement period Feed offered and left after eating of individual cow were collected on 2 consecutive days weekly and at the end of the experiment feed samples were pooled to make representative samples for proximate and detergent analyses. Daily milk yields were recorded. Milk sample and dry matter intake were collected in 2 consecutive days weekly. Live weights were recorded at the start and at the end of the experiment. Milk samples were taken on 56 days of the experiment and subjected to milk choline. Blood parameters were also analyzed. The results showed no statistical significant differences in intakes, live weight change, milk compositions and blood parameters ( $\mathrm{p}>0.05$ ) however, milk yield, $3.5 \%$ fat-corrected-milk yield, milk component yields and milk choline were increased by biotin and rumen-protected choline supplementation. It is recommended in the present study that the addition of $20 \mathrm{mg}$ day ${ }^{-1}$ biotin and $20 \mathrm{~g}_{\text {day }}{ }^{-1}$ rumen-protected choline could be beneficial to lactating dairy cows in early lactation.
\end{abstract}

Key words: Biotin, rumen-protected choline milk production, milk composition, blood parameters, dairy cows, Thailand

\section{INTRODUCTION}

Biotin, a water soluble, B-vitamin is essential for the growth of all major rumen bacteria and is also essential for the dairy cow herself. Biotin is a cofactor with enzymes involved in pathways for amino acid metabolism, cellular respiration and both glucose and fatty acid synthesis. Biotin is required for the rumen fermentation of dietary carbohydrate to propionic acid and for the conversion of propionic acid to glucose in the liver. Biotin is also required in hoof horn formation for the production of structural proteins (keratin) and for the production of intracellular cement that bonds together hoof horn cells to form a semi-waterproof barrier to the environment. Both of these factors affect the integrity of the hoof horn and ultimately the hoof health of dairy cows.

Choline, a component of phospholipid and methyl donor, plays an essential role in VLDL synthesis and thereby contributes to fat export from the liver. Earlier studies (Piepenbrink and Overton, 2000; Pinotti et al., 2002; Cooke et al., 2007) suggested that high-producing cows may be choline deficient around parturition which

Corresponding Author: W. Suksombat, School of Animal Production Technology, Institute of Agricultural Technology, Suranaree University of Technology, University Avenue, Amphur Muang, 30000 Nakhon Ratchasima, Thailand 
adversely affects liver functions, especially the synthesis and secretion of VLDL. Higher choline supply may increase milk production (Erdman and Sharma, 1991; Hartwell et al., 2000; Pinotti et al., 2003) but this response is strongly influenced by other nutrients such as protein and methionine (Emmanuel and Kennelly, 1984; Hartwell et al., 2000; Brusemeister and Sudekum, 2006). Dietary choline is degraded rapidly by the rumen microorganisms (Neill et al., 1979; Sharma and Erdman, 1989) hence, supplementation with choline (conveniently as its salt and choline-chloride) is not an effective way to increase choline supply. Therefore, rumen-protected forms of choline have been developed to deliver choline to the small intestine for absorption.

Increases in milk yield due to the addition of biotin (Zimmerly and Weiss, 2001; Majee et al., 2003; Bergsten et al., 1999) and RPC (Erdman and Sharma, 1991; Piepenbrink and Overton, 2003; Baldi and Pinotti, 2006; Zahra et al., 2006; Lima et al., 2007; Davidson et al., 2008) were previously observed. Recent research work, Suksombat et al. (2011a) fed lactating dairy cows 20 and $40 \mathrm{~g} \mathrm{RPC} \mathrm{day}^{-1}$ found significant increases in milk yield and $3.5 \%$ FCM due to RPC supplementation while Suksombat et al. (2011b) supplemented dairy cows with 20 and $40 \mathrm{mg}^{\text {biotin }}$ day $^{-1}$ and found no significant differences in milk yield and milk composition. In addition, when $40 \mathrm{mg}$ of biotin was compared to $20 \mathrm{mg}$ there was no additional response (Majee et al., 2003). The present study therefore designed to determine the effects of biotin $\left(20 \mathrm{mg} \mathrm{day}^{-1}\right.$ ) and RPC (20 and $40 \mathrm{~g} \mathrm{day}^{-1}$ ) on performances of lactating dairy cows.

\section{MATERIALS AND METHODS}

Animals and treatments: About 24 Holstein Friesian crossbred lactating dairy cows averaging $48 \pm 13$ days in milk, $15.5 \pm 0.8 \mathrm{~kg}$ of milk and $380 \pm 19 \mathrm{~kg}$ body weight were blocked by milking days first and then stratified random balanced for milk yield and body weight into 3 groups of 8 cows. The 1 st group (control) received approximately $6 \mathrm{~kg}$ of $21 \% \mathrm{CP}$ concentrate. The second group was fed the same basal diet as the control group and supplemented with $20 \mathrm{mg}^{-1 a y}{ }^{-1}$ of Biotin (BASF (Thai) Co., Ltd.) filled in a capsule and $20 \mathrm{~g} \mathrm{RPC} \mathrm{day}^{-1}$ topdressed (Reashure ${ }^{\text {( }}$, Balchem Co., Ltd.) and the 3rd group was fed the same basal diet as the control group and supplemented with $20 \mathrm{mg}$ day $^{-1}$ of biotin filled in a capsule and $40 \mathrm{~g}$ RPC day $^{-1}$ top-dressed. Reashure ${ }^{\circledR}$ contains $25 \%$ choline in a chemical form of cholinechloride hence, Reashure ${ }^{\circledR}$ fed at 80 and $160 \mathrm{~g} \mathrm{day}^{-1}$ to provide 20 and $40 \mathrm{~g} \mathrm{day}^{-1}$ of choline, respectively. All cows also received ad libitum grass silage (Brachiaria ruziziensis; 55 days cutting age) had free access to clean water and were individually housed in a free-stall unit and individually fed according to treatments. The experiment lasted for 10 weeks with the 1 st 2 weeks as the adjustment period followed by 8 weeks of measurement period.

Measurements, sample collection and chemical analysis: Feeds offered and residues left after eating of individual cows were weighed for two consecutive days of each period and samples were taken and dried at $60^{\circ} \mathrm{C}$ for $48 \mathrm{~h}$. At the end of the experimental period, feed samples were composited and subsamples were taken for further chemical analysis. Samples were ground through a $1 \mathrm{~mm}$ screen and subjected to proximate analysis. The crude protein content was determined by Kjeldahl analysis (AOAC, 1998). Ether extract was determined using petroleum ether in a Soxtec System (AOAC, 1998). Neutral detergent fiber and acid detergent fiber were determined using the method described by Van Soest et al. (1991) adapted for Fiber Analyzer. Chemical analysis was expressed on the basis of the final DM.

Cows were milked twice daily at 05.00 and $15.00 \mathrm{~h}$ and milk yields were recorded for each cow. Samples of milk (evening + morning) were collected at each milking for 2 consecutive days weekly and stored at $4^{\circ} \mathrm{C}$ with a preservative (bronopol tablet; D and F Control System, San Ramon, CA) until analyzed for fat, protein, lactose and solid-not-fat contents using a Milko-Scan S50 analyzer (Tecator, Denmark). All cows were weighed at the start and end of the experiment.

Milk choline analysis: On day 50, milk sample was collected from individual cow, freeze-dried and stored frozen at $-20^{\circ} \mathrm{C}$ for milk choline analysis. Milk choline was determined by the Enzymatic Method of Woollard and Indyk (2000). Briefly, $5 \mathrm{~g}$ of freeze-dried sample was digested by $30 \mathrm{~mL}$ of $1.0 \mathrm{M}$ hydrochloric acid at $70^{\circ} \mathrm{C}$ for $3 \mathrm{~h}$ to release the majority of bound choline. After cooling, $\mathrm{pH}$ was adjusted with $50 \% \mathrm{NaOH}$ to $3.5-4.0$. The hydrolysate was diluted to $50 \mathrm{~mL}$ with water and filtered. The residual choline from phospholipids was cleaved with phospholipase D (Sigma Type VI, P-8023, from Streptomyces chromofuscus, 150 unit $\mathrm{mg}^{-1}$, unit definition: 1 unit liberates $1.0 \mathrm{mmol}$ choline from L-aphosphatidyl choline $\mathrm{h}^{-1}$ at $\mathrm{pH} 5.0$ at $30^{\circ} \mathrm{C}$; SigmaAldrich, St. Louis, USA). Free choline reacted with choline oxidase (Sigma C-5896, from Alcaligenes species, 10 unit $\mathrm{mg}^{-1}$, unit definition: 1 unit forms 
$1.0 \mathrm{mmol} \mathrm{H} \mathrm{H}_{2}$ with oxidation of $1 \mathrm{mmol}$ choline to betaine aldehyde/min at $\mathrm{pH} 8.0$ at $37^{\circ} \mathrm{C}$; Sigma-Aldrich) liberating hydrogen peroxide. In the presence of peroxidase (Sigma

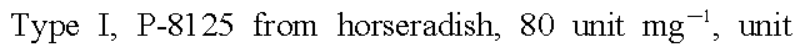
definition: 1 unit forms $1.0 \mathrm{mg}$ purpurogallin from pyrogallol in $20 \mathrm{sec}$ at $\mathrm{pH} 6.0$ at $20^{\circ} \mathrm{C}$; Sigma-Aldrich), phenol is oxidized forming a chromophore with 4aminoantipyrine (Sigma A-4382; Sigma-Aldrich). Absorbance of this compound was measured at $505 \mathrm{~nm}$.

Choline level was calculated as choline hydroxide by the mean of a standard solution prepared by dissolving $523 \mathrm{mg}$ of choline bitartarate (Sigma C-2654; SigmaAldrich) in $100 \mathrm{~mL}$ of water which was equal to $2500 \mathrm{mg} \mathrm{mL} \mathrm{m}^{-1}$ choline hydroxide solution. The fivepoint standard curve $\left(50,100,150,200\right.$ and $250 \mathrm{mg} \mathrm{mL}^{-1}$ choline hydroxide equivalent) was prepared by further diluting the standard solution in water. This method measures the total choline in milk: free choline plus choline bound as acetylcholine, phosphatidylcholine, lysophosphatidylcholine, sphingomyelin and glycerophosphocholine.

Plasma analysis: Jugular vein blood samples were taken before the first feed of the day, on 50 days of the experimental period. The samples were collected into heparinized tubes (Venoject ${ }^{\oplus ;}$ Terumo Europe, Leuven, Belgium) and centrifuged $\left(14,000 \mathrm{~g}\right.$ for $15 \mathrm{~min}$ at $\left.10^{\circ} \mathrm{C}\right)$ to obtain plasma which was stored at $-20^{\circ} \mathrm{C}$ until analysis for glucose (Sigma Chemical Co., St. Louis, MO, USA), Non-esterified Fatty Acids 4 (NEFA) (Enzycolor, Japan), cholesterol (Siegel and Bowdoin, 1971) and $\beta$-hydroxybutyrate (Sigma Chemical Co., St. Louis, MO, USA).

Statistical analysis: Measurements of intake, milk production, milk composition milk choline and blood parameters were analyzed by ANOVA for a randomized complete block design using the Statistical Analysis System (SAS, 1996). Differences between treatment means were statistically compared using least significant differences (Steel and Torrie, 1980).

\section{RESULTS AND DISCUSSION}

Chemical composition, estimated energy values and degradability of Dry Matter (DM) and Crude Protein (CP) of feeds used in the experiment are shown in Table 1 . The crude fat content and energy values of grass silage were low. This is probably because forage was harvested at a more mature stage (55 days cutting age)
Table 1: Chemical composition of concentrate and grass silage used in the experiment

\begin{tabular}{|c|c|c|}
\hline Dry matter $(\%)$ & Concentrate & Grass silage \\
\hline Dry matter & 94.32 & 28.97 \\
\hline Crude protein & 21.37 & 5.43 \\
\hline Crude fat & 4.11 & 1.59 \\
\hline Ash & 8.94 & 9.09 \\
\hline Crude fiber & 12.35 & 30.29 \\
\hline Non fiber carbohydrate & 33.89 & 15.69 \\
\hline eutra & 38.69 & 69.47 \\
\hline cid detergent fiber & 16.38 & 53.32 \\
\hline cid detergent lignin & 4.12 & 4.60 \\
\hline Neutral detergent insoluble nitrogen & 1.12 & 0.20 \\
\hline Acid detergent insoluble nitrogen & 0.41 & 0.15 \\
\hline $\mathrm{TDN}_{1 \mathrm{X}}(\%)^{1}$ & 68.93 & 53.89 \\
\hline $\mathrm{DE}_{\mathrm{P}}\left(\mathrm{Mcal} \mathrm{kg}^{-1}\right)^{2}$ & 2.98 & 2.41 \\
\hline $\mathrm{ME}_{\mathrm{P}}\left(\mathrm{Mcal} \mathrm{kg}^{-1}\right)^{3}$ & 2.56 & 1.97 \\
\hline $\mathrm{NE}_{\mathrm{LP}}\left(\mathrm{Mcal} \mathrm{kg}^{-1}\right)^{4}$ & 1.62 & 1.19 \\
\hline Effective degradability of Dry Matter (dg DM) & 64.20 & 42.60 \\
\hline Effective degradability of Crude Protein (dg CP) & 67.80 & 50.40 \\
\hline \multicolumn{3}{|c|}{ 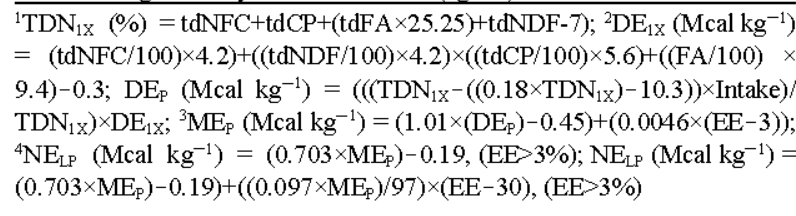 } \\
\hline
\end{tabular}

Table 2: Effects of biotin and rumen-protected choline supplementation on $\mathrm{DM}, \mathrm{CP}$ and $\mathrm{NE}_{\mathrm{LP}}$ intakes of dairy cows

\begin{tabular}{|c|c|c|c|c|c|}
\hline Intake & Control & $\begin{array}{l}20 \mathrm{mg} \text { biotin+ } \\
20 \mathrm{~g} \mathrm{RPC} \mathrm{day}^{-1}\end{array}$ & $\begin{array}{l}20 \mathrm{mg} \text { biotin+ } \\
40 \mathrm{~g} \mathrm{RPC} \mathrm{day}^{-1}\end{array}$ & SEM & p-value \\
\hline \multicolumn{6}{|l|}{ DM (kg) } \\
\hline Concentrate & 7.55 & 7.55 & 7.55 & - & - \\
\hline Grass silage & 6.24 & 6.43 & 6.14 & 0.23 & 0.54 \\
\hline Total & 13.79 & 13.98 & 13.68 & 0.25 & 0.52 \\
\hline \multicolumn{6}{|l|}{ CP $\left(g\right.$ day $\left.^{-1}\right)$} \\
\hline Concentrate & 1613.00 & 1613.00 & 1613.00 & - & - \\
\hline Grass silage & 339.00 & 349.00 & 333.00 & 15.28 & 0.56 \\
\hline Total & 1952.00 & 1962.00 & 1946.00 & 15.58 & 0.53 \\
\hline \multicolumn{6}{|c|}{$\mathrm{NE}_{\mathrm{LP}}\left(\mathrm{Mcal} \mathrm{day}^{-1}\right)$} \\
\hline Concentrate & 12.22 & 12.22 & 12.22 & - & - \\
\hline Grass silage & 7.43 & 7.65 & 7.30 & 0.32 & 0.56 \\
\hline Total & 19.65 & 19.87 & 19.52 & 0.30 & 0.54 \\
\hline
\end{tabular}

SEM = Standard Error of the Mean; RPC = Rumen Protected Choline; $\mathrm{NE}_{\mathrm{LP}}=\mathrm{Net}$ Energy for Lactation at Production level

and consequently resulting in low $\mathrm{DM}$ and $\mathrm{CP}$ degradability (42.6 and 50.4\%, respectively). DM, CP and net energy for lactation $\left(\mathrm{NE}_{\mathrm{LP}}\right)$ intakes of the experimental cows were similar $(\mathrm{p}>0.05)$ (Table 2$)$. The similar DMI of the control and biotin plus RPC-supplemented cows is in agreement with several earlier studies (Erdman and Sharma, 1991; Hartwell et al., 2000; Zimmerly and Weiss, 2001; Margerison et al., 2003; Piepenbrink and Overton, 2003; Pinotti et al., 2003; Rosendo et al., 2004; Zahra et al., 2006). However, only one trial, Majee et al. (2003) found increases in DMI (0.7-1.3 kg days $\left.{ }^{-1}\right)$ when $20 \mathrm{mg} \mathrm{day}{ }^{-1}$ of biotin was supplemented. Dry Matter (DM), Crude Protein (CP) and Net Energy for lactation $\left(\mathrm{NE}_{\mathrm{LP}}\right)$ intakes of the experimental cows were similar $(p>0.05)$ (Table 3). Similar results were previously reported 


\begin{tabular}{|c|c|c|c|c|c|}
\hline Yields & Control & $20 \mathrm{mg}$ biotin $+20 \mathrm{~g} \mathrm{RPC} \mathrm{day}{ }^{-1}$ & $20 \mathrm{mg}$ biotin $+40 \mathrm{~g} \mathrm{RPC} \mathrm{day}{ }^{-1}$ & SEM & $\mathrm{p}$-value \\
\hline Milk yield (kg day $\left.{ }^{-1}\right)$ & $15.30^{b}$ & $16.20^{\mathrm{ab}}$ & $16.60^{\mathrm{a}}$ & 0.29 & 0.047 \\
\hline $3.5 \%$ FCM $\left(\mathrm{kg} \mathrm{day}^{-1}\right)$ & $16.50^{b}$ & $17.90^{\mathrm{a}}$ & $18.40^{\mathrm{a}}$ & 0.31 & 0.036 \\
\hline Fat $(\%)$ & 3.98 & 4.13 & 4.15 & 0.11 & 0.446 \\
\hline Protein (\%) & 2.99 & 3.02 & 3.06 & 0.09 & 0.867 \\
\hline Lactose (\%) & 4.83 & 4.87 & 4.91 & 0.06 & 0.892 \\
\hline Solid not fat (\%) & 8.52 & 8.59 & 8.67 & 0.13 & 0.947 \\
\hline Total solid (\%) & 12.50 & 12.72 & 12.82 & 0.20 & 0.707 \\
\hline Fat yield $\left(\mathrm{g} \mathrm{day}^{-1}\right)$ & $609.00^{b}$ & $669.00^{\mathrm{ab}}$ & $689.00^{\mathrm{a}}$ & 18.90 & 0.042 \\
\hline Protein yield $\left(g_{\text {day }}{ }^{-1}\right)$ & $457.00^{b}$ & $489.00^{\mathrm{ab}}$ & $508.00^{\mathrm{a}}$ & 12.40 & 0.045 \\
\hline Lactose yield $\left(\mathrm{g} \mathrm{day}^{-1}\right)$ & $739.00^{b}$ & $789.00^{\mathrm{ab}}$ & $815.00^{\mathrm{a}}$ & 16.20 & 0.042 \\
\hline Solid not fat yield $\left(\mathrm{g}_{\text {day }}{ }^{-1}\right)$ & $1304.00^{b}$ & $1392.00^{\mathrm{ab}}$ & $1439.00^{\mathrm{a}}$ & 32.10 & 0.043 \\
\hline Total solid yield $\left(\mathrm{g} \mathrm{day}^{-1}\right)$ & $1913.00^{b}$ & $2061.00^{\mathrm{ab}}$ & $2128.00^{\mathrm{a}}$ & 34.50 & 0.049 \\
\hline Initial live weight $(\mathrm{kg})$ & 378.00 & 382.00 & 381.00 & 9.64 & 0.827 \\
\hline Final live weight (kg) & 398.00 & 404.00 & 406.00 & 9.95 & 0.730 \\
\hline Live weight change ( $\mathrm{g} \mathrm{day}^{-1}$ ) & +357.00 & +393.00 & +438.00 & 116.30 & 0.958 \\
\hline
\end{tabular}

$\mathrm{SEM}=$ Standard Error of the Mean; FCM = Fat Corrected Milk; RPC $=$ Rumen Protected Choline

when cows were supplemented with $20-30 \mathrm{mg}^{\text {day }}{ }^{-1}$ of biotin (Zimmerly and Weiss, 2001; Margerison et al., 2003; Rosendo et al., 2004). However, Majee et al. (2003) found increases in DMI (0.7-1.3 $\mathrm{kg}$ day $\left.^{-1}\right)$ when $20 \mathrm{mg} \mathrm{day}^{-1}$ of biotin was supplemented. The main differences between the three studies and the latter were: different duration of the trials, different forage program with corn or grass silage vs alfalfa silage. How these factors may be related to the different intake response to biotin supplementation between the trials is unclear. Supplementing transition cows with rumen-protected choline before calving did not influence DM intake prepartum but when supplemented after calving, it tended to increase postpartum intake (Lima et al., 2007). Feed intake responses to supplemental rumen-protected choline have been variable and some studies have reported no effects (Erdman and Sharma, 1991; Hartwell et al., 2000; Piepenbrink and Overton, 2003; Zahra et al., 2006) whereas others observed an increase in DM intake (Oelrichs et al., 2004; Chung et al., 2005). It is unknown the mechanism by which choline might influence DM intake but it is plausible to speculate an indirect effect mediated by improved postparturient health. Differences in response to rumen-protected choline might also be related to the quality of the product used and method of protection against rumen degradation as differences in the degree of rumenprotection have been shown for different products (Kung et al., 2003).

Recent researches, Suksombat et al. (2011a) found no significant differences in milk yield and milk composition in response to biotin supplementation however, Suksombat et al. (2011b) found increases in milk yield and milk component yields due to rumen-protected choline supplementation. Increasing the intestinal supply of choline has usually improved milk production in lactating dairy cows approximately $7 \%$ over controls (Baldi and Pinotti, 2006) and this improvement seemed independent on the dose of rumen-protected choline supplemented to cows which ranged from 6-60 g day ${ }^{-1}$. Erdman and Sharma (1991) conducted 2 experiments to evaluate the effect of different levels of rumen-protected choline and interaction between choline and dietary CP level in cows past 5 weeks of lactation. In experiment 1 , milk yield tended to increase with feeding of rumen-protected choline and intake of choline chloride ranged from 17-50 $\mathrm{g} \mathrm{day}^{-1}$. In experiment 2 increasing intake of rumen-protected choline from $0-55 \mathrm{~g} \mathrm{day}^{-1}$ of choline chloride resulted in a linear increase in milk yield despite dietary protein content (Erdman and Sharma, 1991). Generally, yields of milk and $3.5 \%$ fat-corrected milk in response to rumen-protected choline have either been unaltered (Hartwell et al., 2000; Guretzky et al., 2006; Davidson et al., 2008) or increased (Erdman and Sharma, 1991; Piepenbrink and Overton, 2003; Zahra et al., 2006; Lima et al., 2007; Davidson et al., 2008). In the present study, it seems likely that increases in milk yield and milk component yields depend solely on rumen-protected choline supplementation since previous research found no significant difference in milk yield due to biotin supplementation (Suksombat et al., 201 1a) while milk yield was increased by rumen-protected choline supplementation (Suksombat et al., 2011b).

Milk component yields were increased by biotin and rumen-protected choline supplementation in the present study. Increased yields of milk components from feeding rumen-protected choline have generally been the result of increased milk yield with some effects on milk fat content but little or no effect on milk protein content. Because choline is used for phospholipid synthesis, it has been suggested that supplementation with choline may facilitate lipid absorption and transport, thereby favoring milk fat synthesis (Erdman et al., 1984) however, more detailed research on blood lipids revealed that supplementation with rumen-protected choline did not alter the concentrations of different lipid fractions in plasma of lactating Holstein cows (Guretzky et al., 2006). 
Table 4: Effect of rumen-protected choline supplementation on milk choline and blood parameters

\begin{tabular}{lccccc}
\hline Parameters & Control & $20 \mathrm{mg}$ biotin $+20 \mathrm{~g} \mathrm{RPC} \mathrm{day}^{-1}$ & $20 \mathrm{mg}$ biotin $+40 \mathrm{~g} \mathrm{RPC} \mathrm{day}^{-1}$ & SEM & $\mathrm{p}$-value \\
\hline Milk choline $\left(\mathrm{mg} \mathrm{kg}^{-1}\right)$ & $97.50^{b}$ & $136.40^{a}$ & $142.70^{\mathrm{a}}$ & 5.70 & 0.034 \\
Plasma glucose $\left(\mathrm{mmol} \mathrm{L}^{-1}\right)$ & 4.31 & 4.42 & 4.46 & 0.07 & 0.762 \\
Plasma BHBA $\left(\mathrm{mmol} \mathrm{L}^{-1}\right)$ & 0.54 & 0.52 & 0.53 & 0.04 & 0.915 \\
Plasma NEFA (mmol L & 0.59 & 0.53 & 0.54 & 0.04 & 0.891 \\
Plasma cholesterol $\left(\mathrm{mmol} \mathrm{L}^{-1}\right)$ & 3.82 & 4.06 & 4.11 & 0.11 & 0.776 \\
NEFA/Cholesterol & 0.15 & 0.13 & 0.13 & 0.02 & 0.824 \\
\hline
\end{tabular}

$\mathrm{RPC}=$ Rumen Protected Choline; BHBA = $\beta$-Hydroxyl Butyrate; NEFA = Non-Esterified Fatty Acids; SEM = Standard Error of the Mean; Means within a row with different superscript differ $(p<0.05)$

In early lactation, plasma nonesterified fatty acids supplies the majority of fatty acids secreted by the mammary gland in dairy cows and this can increase if weight loss postpartum is exacerbated. Because rumen-protected choline might reduce fat mobilization based on plasma nonesterified fatty acid concentrations (Pinotti et al., 2002; Cooke et al., 2007), it is possible that potential effects of choline on intestinal lipid absorption, hepatic triacylglycerol secretion and subsequent transport to the mammary gland might be masked by the reduced availability of nonesterified fatty acids for uptake by the mammary cells.

Milk choline concentration increased for both supplemented groups (Table 4 ). A similar increase in milk-free choline was found by Newbold et al. (2005). The diet in their experiment did not contain any choline supplementation and the milk choline concentration and yield were measured over the period from 15 until 90 DIM. The researchers reported an $82 \%$ increase in milk choline concentration and a $117 \%$ increase in choline yield between 15 and 30 DIM. Bitman and Wood (1990) studied the concentration of phospholipids in milk on days $3,7,42$ and 180 of lactation. An increase was reported between 3 and 7 days but a steady decline was observed between 7 and 180 DIM which might be a consequence of significantly decreasing milk fat concentration. The phospholipid fraction of milk fat was continuously increased during the 1 st 42 days of lactation but free choline unfortunately was not measured in their experiment. The RPC-supplemented group showed higher milk choline concentration than the control group. The higher milk choline level provides evidence that choline in the experimental RPC product escaped ruminal fermentation, absorbed from the small intestine and improved the choline supply of the cows.

Rumen-protected choline supplementation had no effect on plasma levels of glucose (4.31 vs. 4.42 and $4.46 \mathrm{mmol} \mathrm{L}^{-1}$ in control, $20 \mathrm{mg}$ biotin $/ 20 \mathrm{~g}$ RPC animals and $20 \mathrm{mg}$ biotin/40 $\mathrm{g}$ RPC animals), $\beta$-hydroxybutyrate ( 0.54 vs. 0.52 and $0.53 \mathrm{mmol} \mathrm{L}^{-1}$ ), cholesterol ( 3.82 vs. 4.06 and $4.11 \mathrm{mmol} \mathrm{L}^{-1}$ ), NEFA (0.59 vs. 0.53 and 0.54 $\mathrm{mmol} \mathrm{L}^{-1}$ ) or the $\mathrm{NEFA} /$ cholesterol ratio (0.15 vs. 0.13 and 0.13 ) (Table 4).

\section{CONCLUSION}

Feeding biotin and RPC did not alter intakes, milk composition, live weight change and blood parameters however, milk yield, 3.5\% fat-corrected-milk yield, milk component yields and milk choline concentration were increased for both supplemented groups. RPC supplementation significantly increased milk choline concentration indicating better choline supply to these cows. It is recommended that approximate $20 \mathrm{~g} \mathrm{day}^{-1}$ of RPC could be added to lactating dairy cow's diet for better beneficial response.

\section{ACKNOWLEDGEMENTS}

Researchers would like to express special thanks to the Muaklek Dairy Cooperative, the Center for Scientific and Technological Equipment for their great support. Financial support was provided by the Institute of Research and Development, Suranaree University of Technology. Biotin was provided by BASF (Thai) Co., Ltd. Thailand while rumen-protected choline was provided by Eurotec Nutrition (Thailand) Co., Ltd. Thailand.

\section{REFERENCES}

AOAC, 1998. Official Method of Analysis. AOAC., Washington DC., USA.

Baldi, A. and L. Pinotti, 2006. Choline metabolism in high-producing dairy cows: Metabolic and nutritional basis. Can. J. Anim. Sci., 86: 207-212.

Bergsten, C., P.R. Greenough, R.C. Dobson and J. Gay, 1999. A controlled field trial on the effects of biotin supplementation on milk production and hoof lesions. J. Dairy Sci., 82: 34-34.

Bitman, J. and D.L. Wood, 1990. Changes in milk fat phospholipids during lactation. J. Dairy Sci., 73: $1208-1216$.

Brusemeister, F. and K.H. Sudekum, 2006. Rumenprotected choline for dairy cows: The in situ evaluation of a commercial source and literature evaluation of effects on performance and interactions between methionine and choline metabolism. Anim. Res., 55: 93-104. 
Chung, Y.H., T.W. Cassidy, I.D. Girard, P. Cavassini and G.A. Varga, 2005. Effect of rumen-protected choline and dry propylene glycol on feed intake and blood metabolites of Holstein dairy cows. J. Dairy Sci., 88: 61-61.

Cooke, R.F., N.S.D. Rio, D.Z. Caraviello, S.J. Bertics, M.H. Ramos and R.R. Grummer, 2007. Supplemental choline for prevention and alleviation of fatty liver in dairy cattle. J. Dairy Sci., 90: 2413-2418.

Davidson, S., B.A. Hopkins, J. Odle, C. Brownie, V. Fellner and L.W. Whitlow, 2008. Supplementing limited methionine diets with rumen-protected methionine betaine and choline in early lactation Holstein cows. J. Dairy Sci., 91: 1552-1559.

Emmanuel, B. and J.J. Kennelly, 1984. Kinetics of methionine and choline and their incorporation into plasma lipids and milk components in lactating goats. J. Dairy Sci., 67: 1912-1918.

Erdman, R.A. and B.K. Sharma, 1991. Effect of dietary rumen-protected choline in lactating dairy cows. J. Dairy Sci., 74: 1641-1647.

Erdman, R.A., R.D. Shaver and J.H. Vandersall, 1984. Dietary choline for the lactating cow: Possible effects on milk fat synthesis. J. Dairy Sci., 67: 410-415.

Guretzky, N.A.J., D.B. Carlson, J.E. Garrett and J.K. Drackley, 2006. Lipid metabolite profiles and milk production for holstein and jersey cows fed rumen-protected choline during the periparturient period. J. Dairy Sci., 89: 188-200.

Hartwell, J.R., M.J. Cecava and S.S. Donkin, 2000. Impact of dietary rumen undegradable protein and rumen-protected choline on intake, peripartum liver triacylglyceride, plasma metabolites and milk production in transition dairy cows. J. Dairy Sci., 83: 2907-2917.

Kung, L., D.E. Putnam and J.E. Garrett, 2003. Comparison of commercially available rumen-stable choline products. J. Dairy Sci., 86: 275-275.

Lima, F.S., M.F. Sa Filho, L.F. Greco, F. Susca, V.J. Magalhaes, J. Garrett and J.E.P. Santos, 2007. Effects of feeding rumen-protected choline (RPC) on lactation and metabolism. J. Dairy Sci., 90: 174-174.

Majee, D.N., E.C. Schwab, S.J. Bertics, W.M. Seymour and R.D. Shaver, 2003. Lactation performance by dairy cows fed supplemental biotin and a B-vitamin blend. J. Dairy Sci., 86: 2106-2112.

Margerison, J.K., B. Winkler, G. Penny and A. Packington, 2003. The effect of biotin supplementation on milk yield, reproduction and lameness in dairy cattle. J. Dairy Sci., 86: 250-250.

Neill, A.R., D.W. Grime, A.M. Snoswell, A.J. Northrop, D.B. Lindsay and R.M. Dawson, 1979. The low availability of dietary choline for the nutrition of sheep. Biochem. J., 180: 559-565.
Newbold, J.R., E.C.L. Bleach, P.C. Aikman and D.E. Beever, 2005. Secretion of choline in milk is depressed in dairy cows in early lactation. J. Dairy Sci., 88: 61-65.

Oelrichs, W.A., M.C. Lucy, M.S. Kerley and J.N. Spain, 2004. Feeding soybeans and rumen-protected choline to dairy cows during the periparturient period and early lactation: Effects on production and energy balance. J. Dairy Sci., 87: 344-344.

Piepenbrink, M.S. and T.R. Overton, 2000. Liver metabolism and production of periparturient dairy cattle fed rumen-protected choline. J. Dairy Sci., 83: $257-257$.

Piepenbrink, M.S. and T.R. Overton, 2003. Liver metabolism and production of cows fed increasing amounts of rumen-protected choline during the periparturient period. J. Dairy Sci., 86: 1722-1733.

Pinotti, L., A. Baldi and V. Dell'Orto, 2002. Comparative mammalian choline metabolism with emphasis on the high-yielding dairy cow. Nutr. Res. Rev., 15: 315-331.

Pinotti, L., A. Baldi, I. Politis, R. Rebucci, L. Sangalli and V. Dell'Orto, 2003. Rumen-protected choline administration to transition cows: Effects on milk production and vitamin E status. J. Vet. Med. A. Physiol. Pathol. Clin. Med., 50: 18-21.

Rosendo, O., C.R. Staples, L.R. McDowell, R. McMahon and L. Adinga et al., 2004. Effects of biotin supplementation on peripartum performance and metabolites of Holstein cows. J. Dairy Sci., 87: 2535-2545.

SAS, 1996. SAS User's Guide: Statistics, SAS, Institute, Cary, NC.

Sharma, B.K. and R.A. Erdman, 1989. In vitro degradation of choline from selected feedstuffs and choline supplements. J. Dairy Sci., 72: 2772-2776.

Siegel, A.L. and B.C. Bowdoin, 1971. Modification of an automated procedure for serum cholesterol which permits the quantitative estimation of cholesterol esters. Clin. Chem., 17: 229-230.

Steel, R.G.D. and J.H. Torrie, 1980. Principles and Procedures of Statistics: A Biometric Approach. 2nd Edn., McGraw Hill Book Co. Inc., New York, USA., ISBN-13: 9780070610286 , Pages: 633.

Suksombat, W., P. Lounglawan and P. Paengsai, 2011a. Effects of biotin supplementation on milk production, milk composition, milk fatty acids, ruminal $\mathrm{pH}$, ammonia nitrogen and volatile fatty acids in lactating dairy cows. J. Anim. Vet. Adv., 10: 2186-2192.

Suksombat, W., R. Mirattanaphrai and P. Paengsai, 2011 b. Perfromance of lactating dairy cows in response to supplementation of rumen-protected choline. J. Anim. Vet. Adv., 10: 3321-3327. 
Van Soest, P.J., J.B. Robertson and B.A. Lewis, 1991. Methods for dietary fiber, neutral detergent fiber and nonstarch polysaccharides in relation to animal nutrition. J. Dairy Sci., 74: 3583-3597.

Woollard, D.C. and H.R. Indyk, 2000. Determination of choline in milk and infant formulas by enzymatic analysis: Collaborative study. J. AOAC. Int., 83: $131-138$.
Zahra, L.C., T.F. Duffield, K.E. Leslie, T.R. Overton, D. Putnam and S.J. LeBlanc, 2006. Effects of rumenprotected choline and monensin on milk production and metabolism of periparturient dairy cows. J. Dairy Sci., 89: 4808-4818.

Zimmerly, A. and W.P. Weiss, 2001. Effects of supplemental dietary biotin on performance of Holstein cows during early lactation. J. Dairy Sci., 84: 498-506. 